$$
\text { - } 981 \text { - }
$$

\title{
EFFECT OF DIFFERENT SEED MOISTURE CONTENT AT HARVEST ON SOME MORPHOLOGICAL AND YIELD CHARACTERISTICS OF DIFFERENT RICE CULTIVARS (ORYZA SATIVA L.)
}

\author{
Aboukhadrah, S. H. ${ }^{1}$ - Mohamed, A. A. A. ${ }^{1}-$ ELKhoby, W. ${ }^{2}-$ Shahen, F. F. ${ }^{2 *}$ \\ ${ }^{1}$ Agronomy Department, Fac. of Agric., Kafr-El-Sheikh Univ., Kafr-El-Sheikh, Egypt \\ ${ }^{2}$ Rice Research \& Training Center, Field Crop Research Institute, ARC, Giza, Egypt \\ *Corresponding author \\ e-mail: Shahin.fathy@yahoo.com
}

(Received $15^{\text {th }}$ Apr 2020; accepted $7^{\text {th }}$ Oct 2020)

\begin{abstract}
This experiment study the effects of different seed moisture contents (22, 20, 18, 16 and 14\%) on some morphological and yield characters of some rice cultivars, Sakha 105, Sakha 106, Giza 179, Giza 178, Giza 182 and hybrid 2034. The moisture contents were assigned in main plot, while the rice cultivars were assigned in subplot, the main cultural practices were applied according to Rice Research \&Training Center. The results showed that, the highest seed volume was recorded under the highest moisture content, but the lowest moisture content resulted in the lowest values for the remaining studied characters, on the other hand Sakha 106 was recorded to have the highest seed volume, plant height and 1000 grain weight, while, the Hybrid 2034 and Giza 178 were recorded the highest germination \% and grain yield t/ha, which means the seeds should be died to $14 \%$ after harvesting and before storage to maintain the seed viability and increase the productivity. Finally, we concluded that, highest seed volume, plant height and 1000 grain weight was recorded in the case of Sakha 106, while the highest germination \% and grain yield (t/ha) was recorded in the Hybrid 2034 and Giza 178, which means that the seeds should be dried to $14 \%$ moisture content after the harvested and before storage to maintain the seed viability and increase the productivity. Finally, the optimum date for harvesting rice cultivars under study should be determined.
\end{abstract}

Keywords: rice varieties, grain weight and germination

\section{Introduction}

Rice is the most important stable food for more than half of the world's population, mostly in the developing countries. It is ranked after wheat directly and after maize by two places among food crops in the world (Badawai, 2005). Human consumption accounts for $85 \%$ of total production for rice, compared with $72 \%$ for wheat and $19 \%$ for maize (Aidy et al., 2002). The total cultivated area in Egypt was 0.858 million fed. $\left(3.603 .600 \mathrm{~m}^{2}\right)$, and the total production was 1.32 million ton (RRTC, 2015). High quality seed produce high rice production. Seed of improved varieties can trigger change and help bring about agricultural production objectives. High quality seed lots may improve crop yield in two ways: first, because seedling emergence from the seedbed is rapid and uniform, leading to the production of vigorous plants, and second because the percentage of seedling emergence is high, so optimum plant population density could be achieved under a wide range of environmental condition. These are the main motivations for farmers, who are interested in buying and cultivating vigorous seeds, thus production of high-quality seeds is an important strategy for seed producers. Seed maturation is one of the main components of seed quality and a prerequisite for successful germination and emergence. The rice cultivars significantly differed in all studied traits; rice cultivar Giza 178 exceeded all cultivars in grain and straw yields as well as yield components as yielder 


$$
-982-
$$

cultivar under stress conditions (RRTC, 2015). The moisture content in rice seed is considered as the main factor in high quality seed which increase rice production (Chen, 2003). So, the present investigation was aimed to study the effect of moisture content on some morphological and yield characters of some rice cultivars.

\section{Materials and methods}

Two experiment was conducted at experimental farm of Sakha agricultural research station, kafr El sheikh, Egypt, during three seasons, 2015, 2016 and 2017, to study the effect of different levels of moisture contents on some morphological and yield characters of some rice cultivars, the six rice cultivars were collected for every season during October 2015 and 2016 with different moisture content (14, 16, 18, 20, 22\%) and storage up to sowing in May 1st 2016 the samples were collected during harvest in the field with different moisture content and kept or stored up to start the next season in May. Optimum to sowing date for rice crop this method was repeated during the 2017 season, the design experiment was split plot design with three replications, the main plot was assigned for moisture contents and the cultivars were assigned in subplot with plot size $\left(5 \mathrm{~m}^{2}\right)$ and the remaining cultural practices were applied according to RRTC (2015). The measurements were recorded on grain volume, germination $\%$, plant height, seed set \%, 1000 grain weight and grain yield (t/ha) according to SES to IRRI (2008).

Table 1. Monthly maximum and minimum temperature $(\mathrm{Co})$, relative humidity $\%$ and wind velocity $(\mathrm{km} / \mathrm{h})$ at RRTC Sakha, Kafr EL-Skeikh province during 2016 and 2017 seasons

\begin{tabular}{|c|c|c|c|c|c|c|c|c|c|c|}
\hline \multirow{3}{*}{ Month } & \multicolumn{5}{|c|}{2016 season } & \multicolumn{5}{|c|}{2017 season } \\
\hline & \multicolumn{2}{|c|}{$\begin{array}{c}\text { Temperature } \\
\left({ }^{\circ} \mathbf{C}\right)\end{array}$} & \multicolumn{2}{|c|}{$\begin{array}{c}\text { Relative humidity } \\
(\%)\end{array}$} & \multirow{2}{*}{$\begin{array}{c}\text { Wind } \\
\text { velocity } \\
(\mathrm{km} / \mathrm{h})\end{array}$} & \multicolumn{2}{|c|}{ Temperature $\left({ }^{\circ} \mathrm{C}\right)$} & \multicolumn{2}{|c|}{$\begin{array}{c}\text { Relative humidity } \\
(\%)\end{array}$} & \multirow{2}{*}{$\begin{array}{c}\text { Wind } \\
\text { velocity } \\
(\mathrm{km} / \mathrm{h})\end{array}$} \\
\hline & Max & Min & $7.30 \mathrm{AM}$ & 13.30PM & & Max & Min & $7.30 \mathrm{AM}$ & 13.30PM & \\
\hline April & 25.64 & 13.7 & 78.30 & 78.50 & 95.70 & 27.8 & 20.0 & 80.9 & 48.9 & 74.0 \\
\hline May & 30.19 & 18.79 & 77.30 & 46.10 & 114.60 & 31.2 & 23.8 & 75.6 & 43.9 & 95.8 \\
\hline June & 30.85 & 21.14 & 78.80 & 51.20 & 105.30 & 33.6 & 25.3 & 75.5 & 48.0 & 98.6 \\
\hline July & 33.00 & 22.40 & 85.20 & 54.30 & 97.30 & 35.2 & 25.4 & 82.6 & 51.0 & 89.5 \\
\hline August & 35.10 & 25.00 & 83.8 & 51.70 & 91.20 & 34.9 & 25.2 & 82.4 & 51.4 & 76.0 \\
\hline Sept. & 34.60 & 23.80 & 82.70 & 46.50 & 95.30 & 32.8 & 23.5 & 83.1 & 48.3 & 68.7 \\
\hline Oct. & 29.90 & 20.60 & 80.90 & 54.10 & 87.00 & 29.5 & 20.6 & 82.5 & 49.6 & 57.9 \\
\hline
\end{tabular}

\section{Statistical analysis}

All the data collected were subjected to analysis of variance according to Gomez and Gomez (1984). Treatment means were compared using L.S.D. All statistical analysis was performed using analysis of variance technique by means of "COSTAT" computer software.

\section{Results}

The main characters for rice cultivars were show in Table 2. The rice varieties were related to different types:

1. Japonica type had high moisture content.

2. Indica/Japonica type had moderate moisture content.

3. Indica type had low moisture content. 


$$
\text { - } 983 \text { - }
$$

Table 2. The main characters for the studied rice cultivars

\begin{tabular}{c|c|c|c|c|c}
\hline Cultivars & Pedigree & Plant height & 1000 grain wight & Grain yield t/ha & Disease reaction (blast) \\
\hline SAKHA 105 & Japonica & 98 & 29 & 10.100 & $\mathrm{R}$ \\
SAKHA 106 & Japonica & 105 & 28 & 10.250 & $\mathrm{R}$ \\
GIZA 178 & Indica/Japonica & 100 & 21 & 10.500 & $\mathrm{R}$ \\
GIZA 179 & Indica/Japonica & 90 & 26 & 10.400 & $\mathrm{R}$ \\
GIZA 182 & Indica & 90 & 25 & 9.500 & $\mathrm{R}$ \\
SK 2034 (H1) & Indica/Japonica & 100 & 25 & 11.200 & $\mathrm{R}$ \\
\hline
\end{tabular}

The data in Table 3 showed the effect of different levels for moisture content on grain volume, germination $\%$ and plant height, where, in the case of seeds harvested at $14 \%$ moisture content the germination $\%$ increased and plant height enhanced, while in the case of seeds harvested at $22 \%$ moisture content the seed volume increased and the germination $\%$ and plant height decreased indicating that increased seed moisture content increased seed size then volume and quality.

Table 3. Mean performance of some rice varieties with their interaction for grain volume germination \% and plant height during 2016 and 2017 seasons

\begin{tabular}{c|c|c|c|c|c|c}
\hline Treatments \% & \multicolumn{2}{|c|}{ Grain volume $\left.\mathbf{( c m}^{\mathbf{3}}\right)$} & \multicolumn{2}{c|}{ Germination $\mathbf{( \% )}$} & \multicolumn{2}{c}{ Plant height $(\mathbf{c m})$} \\
\hline Moisture & $\mathbf{2 0 1 6}$ & $\mathbf{2 0 1 7}$ & $\mathbf{2 0 1 6}$ & $\mathbf{2 0 1 7}$ & $\mathbf{2 0 1 6}$ & $\mathbf{2 0 1 7}$ \\
\hline 14 & 2.22 & 2.04 & 92.05 & 90.82 & 101.88 & 100.77 \\
16 & 2.37 & 2.18 & 88.06 & 87.05 & 96.18 & 93.88 \\
18 & 2.44 & 2.33 & 84.02 & 82.72 & 92.5 & 91.23 \\
20 & 2.72 & 2.55 & 76.44 & 78.35 & 89.6 & 88.63 \\
22 & 3.00 & 2.71 & 59.69 & 57.29 & 86.52 & 85.37 \\
\hline F-test & $* *$ & $* *$ & $* *$ & $* *$ & $* *$ & $* *$ \\
\hline LSD 0.05 & 0.145 & 0.148 & 0.520 & 0.312 & 0.083 & 0.659 \\
\hline Cultivars & & & & & & 93.13 \\
SAKHA 105 & 2.77 & 2.57 & 84.46 & 83.25 & 91.84 & 93.57 \\
SAKHA 106 & 2.79 & 2.57 & 84.78 & 83.74 & 98.48 & 96.57 \\
GIZA 178 & 2.11 & 2.08 & 82.99 & 83.04 & 96.64 & 95.81 \\
GIZA 179 & 2.96 & 2.84 & 83.32 & 83.19 & 85.19 & 83.83 \\
GIZA 182 & 2.21 & 2.17 & 82.14 & 81.93 & 88.94 & 86.99 \\
SK 2034 (H1) & 2.60 & 2.40 & 84.60 & 83.93 & 98.79 & 98.54 \\
\hline F-test & $* *$ & $* *$ & $* *$ & $* *$ & $* *$ & $* *$ \\
\hline LSD 0.05 & 0.119 & 0.118 & 0.462 & 0.293 & 0.077 & 0.680 \\
\hline Interaction & $* *$ & $* *$ & $* *$ & $* *$ & $* *$ & $* *$ \\
\hline moisture $\times$ varieties & & & & & & \\
\hline
\end{tabular}

*Highly significant at $0.05 \%$ probability

The data in Table 4 show the effect of moisture content of some rice cultivars on seed set $\%, 1000$ grain weight and grain yield (t/ha.) during 2016 and 2017 seasons. The highest values for seed set \%, 1000 grain weight and grain yield (t/ha.) were recorded at $14 \%$ moisture content, while at $22 \%$ moisture content undesirable values were recorded for the studied characters, indicating that $14 \%$ moisture content enhances crop growth rate then 


$$
\text { - } 984 \text { - }
$$

increases the yield attribute finally grain yield ( $\mathrm{t} / \mathrm{ha}$.). For the rice cultivars, in the rice cultivar, Giza 179 desirable values were recorded for seed set $\%$ and 1000 grain weight, but the indicia/japonica cultivars (Egyptian hybrid 1 and Giza 179) recorded the highest grain yield (t/ha.) compared to the japonica rice cultivars (SAKHA 105 and SAKHA 106).

Table 4. Mean performance of some rice varieties with their interaction for seed set, grain weight and grain yield characters during 2016 and 2017 seasons

\begin{tabular}{c|c|c|c|c|c|c}
\hline Treatments & \multicolumn{2}{|c|}{ Seed set (\%) } & \multicolumn{2}{c|}{ 1000- grain weight (g) } & \multicolumn{2}{c}{ Grain yield (t/ha) } \\
\hline Moisture \% & $\mathbf{2 0 1 6}$ & $\mathbf{2 0 1 7}$ & $\mathbf{2 0 1 6}$ & $\mathbf{2 0 1 7}$ & $\mathbf{2 0 1 6}$ & $\mathbf{2 0 1 7}$ \\
\hline 14 & 95.76 & 94.15 & 22.58 & 22.72 & 11.35 & 10.92 \\
16 & 87.56 & 85.59 & 23.04 & 23.66 & 10.28 & 9.80 \\
18 & 82.86 & 80.87 & 23.71 & 24.63 & 10.11 & 9.56 \\
20 & 76.73 & 75.56 & 24.77 & 25.38 & 9.02 & 9.04 \\
22 & 74.94 & 72.61 & 26.13 & 26.49 & 8.40 & 3.28 \\
\hline F- test & $* *$ & $* *$ & $* *$ & $* *$ & $* *$ & $* *$ \\
\hline LSD 0.05 & 0.425 & 0.308 & 0.693 & 0.229 & 0.545 & 0.547 \\
\hline Varieties & & & & & & \\
\hline SAKHA 105 & 83.28 & 80.98 & 25.88 & 25.83 & 9.40 & 8.54 \\
SAKHA 106 & 83.88 & 82.07 & 25.93 & 26.92 & 9.59 & 8.99 \\
GIZA 178 & 84.57 & 82.57 & 20.66 & 2079 & 10.21 & 9.49 \\
GIZA 179 & 84.89 & 82.91 & 25.35 & 25.59 & 10.30 & 9.80 \\
GIZA 182 & 82.05 & 80.01 & 23.62 & 24.79 & 8.97 & 8.44 \\
SK 2034 (H1) & 84.01 & 82.00 & 22.86 & 23.60 & 11.47 & 11.44 \\
\hline F-test & $* *$ & $* *$ & $* *$ & $* *$ & $* *$ & $* *$ \\
\hline LSD 0.05 & 0.362 & 0.240 & 0.542 & 0.229 & 0.477 & 0.428 \\
\hline Interaction & $* *$ & $* *$ & $* *$ & $* *$ & $* *$ & $* *$ \\
moisture $\times$ varieties & & & & & & \\
\hline
\end{tabular}

**Highly significant at $0.05 \%$ probability

The interaction between moisture content and rice varieties are presented in Table 5 and Figure 1, the grain volume affected by the different levels of moisture content, where the high moisture content with most of the rice cultivars recorded the highest value for grain volume compared with the low moisture content.

Table 5. Grain volume $\left(\mathrm{cm}^{3}\right)$ as affected by the interaction between some rice varieties and different moisture content during 2016 and 2017 seasons

\begin{tabular}{|c|c|c|c|c|c|c|c|c|c|c|c|c|}
\hline \multirow{3}{*}{ Moisture } & \multicolumn{12}{|c|}{ Varieties } \\
\hline & \multicolumn{2}{|c|}{ SAKHA105 } & \multicolumn{2}{|c|}{ SAKHA106 } & \multicolumn{2}{|c|}{ GIZA178 } & \multicolumn{2}{|c|}{ GIZA179 } & \multicolumn{2}{|c|}{ GIZA182 } & \multicolumn{2}{|c|}{ HYBRID1 } \\
\hline & 2016 & 2017 & 2016 & 2017 & 2016 & 2017 & 2016 & 2017 & 2016 & 2017 & 2016 & 2017 \\
\hline 14 & 2.30 & 2.10 & 2.50 & 2.30 & 1.80 & 1.66 & 2.66 & 2.66 & 2.66 & 1.80 & 2.10 & 1.93 \\
\hline 16 & 2.50 & 2.30 & 2.56 & 2.36 & 1.85 & 1.68 & 2.80 & 2.80 & 2.80 & 1.90 & 2.46 & 2.26 \\
\hline 18 & 2.73 & 2.53 & 2.59 & 2.49 & 1.90 & 1.70 & 2.70 & 2.70 & 2.70 & 2.03 & 2.56 & 2.36 \\
\hline 20 & 3.06 & 2.86 & 2.62 & 2.80 & 1.95 & 1.75 & 3.17 & 3.17 & 3.17 & 2.25 & 2.86 & 2.66 \\
\hline 22 & 3.26 & 3.06 & 3.68 & 2.92 & 2.50 & 1.83 & 3.50 & 3.50 & 3.50 & 2.45 & 3.03 & 2.83 \\
\hline $\begin{array}{c}\text { LSD } 0.05 \text { at } \\
2016 / 2017\end{array}$ & & & & & & & 261 & & & & & \\
\hline
\end{tabular}




$$
-985 \text { - }
$$

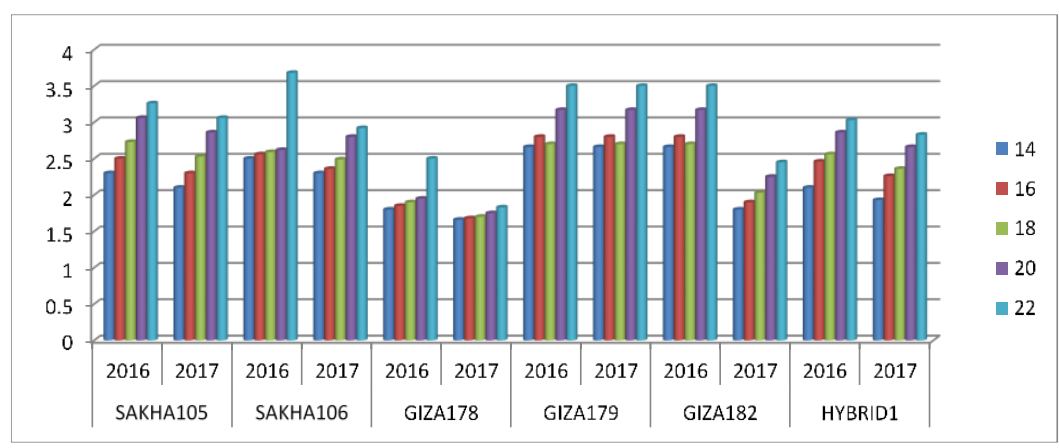

Figure 1. Grain volume $\left(\mathrm{cm}^{3}\right)$ as affected by the interaction between some rice and varieties and different moisture content during 2016 and 2017 seasons

The results in Table 6 and Figure 2 showed. the interaction between rice varieties and different levels of moisture content, the highest value for 1000-grain weight was recorded in the case of the variety Sakha 106 with 14\% moisture content compared to the variety Giza 178 with a moisture content of $28 \%$, during the two seasons. Equally for 1000 grain weight the highest values were recorded $(27.38$ and $28.78 \mathrm{~g})$ when the rice variety Sakha 106 was used with a moisture content of $14 \%$, but the lowest values were recorded (20.69 and $21.72 \mathrm{~g}$ ) with the rice variety Giza 178 at moisture content $22 \%$ during 2016 and 2017 seasons, respectively.

Table 6. 1000 grain weight $(g)$ as affected by the interaction between some rice varieties and different moisture content during 2016 and 2017 seasons

\begin{tabular}{|c|c|c|c|c|c|c|c|c|c|c|c|c|}
\hline \multirow{3}{*}{ Moisture } & \multicolumn{12}{|c|}{ VARIETIES } \\
\hline & \multicolumn{2}{|c|}{ SAKHA105 } & \multicolumn{2}{|c|}{ SAKHA106 } & \multicolumn{2}{|c|}{ GIZA178 } & \multicolumn{2}{|c|}{ GIZA179 } & \multicolumn{2}{|c|}{ GIZA182 } & \multicolumn{2}{|c|}{ HYBRID1 } \\
\hline & 2016 & 2017 & 2016 & 2017 & 2016 & 2017 & 2016 & 2017 & 2016 & 2017 & 2016 & 2017 \\
\hline 14 & 27.00 & 27.00 & 29.16 & 29.16 & 21.66 & 21.66 & 27.55 & 27.66 & 24.83 & 28.00 & 22.66 & 25.46 \\
\hline 16 & 26.66 & 22.66 & 26.33 & 27.33 & 21.33 & 21.33 & 25.66 & 26.66 & 24.66 & 25.33 & 24.00 & 25.00 \\
\hline 18 & 26.00 & 22.50 & 25.66 & 26.66 & 20.66 & 20.66 & 24.66 & 25.66 & 23.33 & 24.33 & 22.00 & 24.00 \\
\hline 20 & 25.50 & 25.00 & 24.33 & 26.00 & 20.00 & 20.33 & 24.46 & 24.66 & 23.00 & 23.66 & 21.33 & 22.33 \\
\hline 22 & 25.00 & 24.00 & 23.55 & 25.00 & 19.66 & 20.00 & 24.33 & 23.33 & 22.66 & 22.66 & 20.33 & 21.33 \\
\hline $\begin{array}{l}\text { LSD } 0.05 \text { at } \\
2016 / 2017\end{array}$ & & & & & & & 2 & & & & & \\
\hline
\end{tabular}

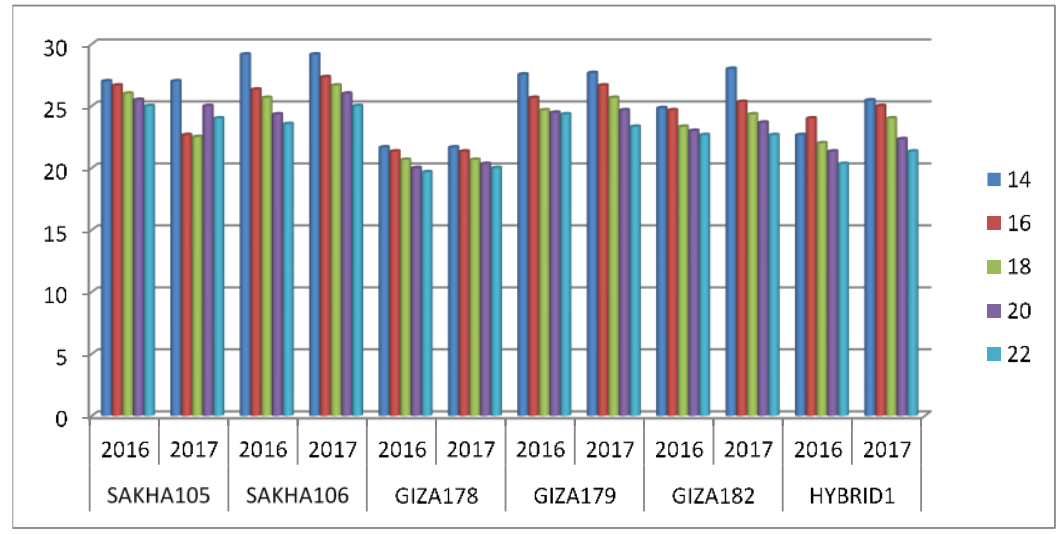

Figure 2. 1000 grain weight $(\mathrm{g})$ as affected by the interaction between some rice and different varieties moisture content during 2016 and 2017 seasons 
That affected on delay the physiological maturity of the seed embryo, then decreased the viability for seed germination and crop growth rate. For rice cultivars, the highest values for grain volumes were recorded in the japonica rice cultivars Sakha 106 and Sakha 105 while in indica/japonica rice cultivars, Giza 178 and Egyptian Hybrid1 the highest values were recorded for germination \%, moreover in the Sakha 106 and hybrid 2034 rice cultivars the highest values were recorded for plant height that referred to the genetic background for the studied cultivars. That affected on delay for physiological maturity of the seed embryo, then decreased the viability for seed germination and crop growth rate. For rice cultivars, the highest values for seed volumes were recorded in the japonica rice cultivars Sakha 106 and Sakha 105, while in indica/japonica rice cultivars, Giza 178 and Egyptian hybrid the highest values were recorded for germination \%, moreover in the Sakha 106 and hybrid 1 rice cultivars the highest values were recorded for plant height that referred to the genetic background for the studied cultivars.

The results in Table 7 and Figure 3 showed the interaction between rice varieties and different levels of moisture content on Germination \%, the rice variety Giza 178 recorded the highest value of germination at $14 \%$ moisture content, while, in the variety Giza 179 the lowest value was recorded at $22 \%$ moisture content, indicating that the Japonica type may be highly affected with high moisture content compared to the indica and indica/Japonica types. Seed vigor is an important aspect of quality, which is controlled by field stand, establishment ability and performance. The problems associated with establishing vigorously growing seedlings are often related to poor seed quality.

Table 7. Germination \% as affected by interaction between some rice and different varieties moisture content during 2016 and 2017 seasons

\begin{tabular}{|c|c|c|c|c|c|c|c|c|c|c|c|c|}
\hline \multirow{3}{*}{ Moisture } & \multicolumn{12}{|c|}{ Varieties } \\
\hline & \multicolumn{2}{|c|}{ SAKHA105 } & \multicolumn{2}{|c|}{ SAKHA106 } & \multicolumn{2}{|c|}{ GIZA178 } & \multicolumn{2}{|c|}{ GIZA179 } & \multicolumn{2}{|c|}{ GIZA182 } & \multicolumn{2}{|c|}{ HYBRID1 } \\
\hline & 2016 & 2017 & 2016 & 2017 & 2016 & 2017 & 2016 & 2017 & 2016 & 2017 & 2016 & 2017 \\
\hline 14 & 93.50 & 90.33 & 91.33 & 90.60 & 94.60 & 93.66 & 91.13 & 90.13 & 91.50 & 92.43 & 94.60 & 92.93 \\
\hline 16 & 88.96 & 87.26 & 86.33 & 85.33 & 88.16 & 87.16 & 87.43 & 86.40 & 88.66 & 87.66 & 88.73 & 87.73 \\
\hline 18 & 84.33 & 83.33 & 83.36 & 81.66 & 82.76 & 83.20 & 83.33 & 81.33 & 84.90 & 83.16 & 85.30 & 83.23 \\
\hline 20 & 80.25 & 78.23 & 79.33 & 77.66 & 79.66 & 78.00 & 78.33 & 78.00 & 80.76 & 79.50 & 79.66 & 78.66 \\
\hline 22 & 76.90 & 75.93 & 76.00 & 75.00 & 76.56 & 75.33 & 75.76 & 74.70 & 76.16 & 75.16 & 76.73 & 75.73 \\
\hline $\begin{array}{l}\text { LSD } 0.05 \text { at } \\
2016 / 2017\end{array}$ & & & & & & & 33 & & & & & \\
\hline
\end{tabular}

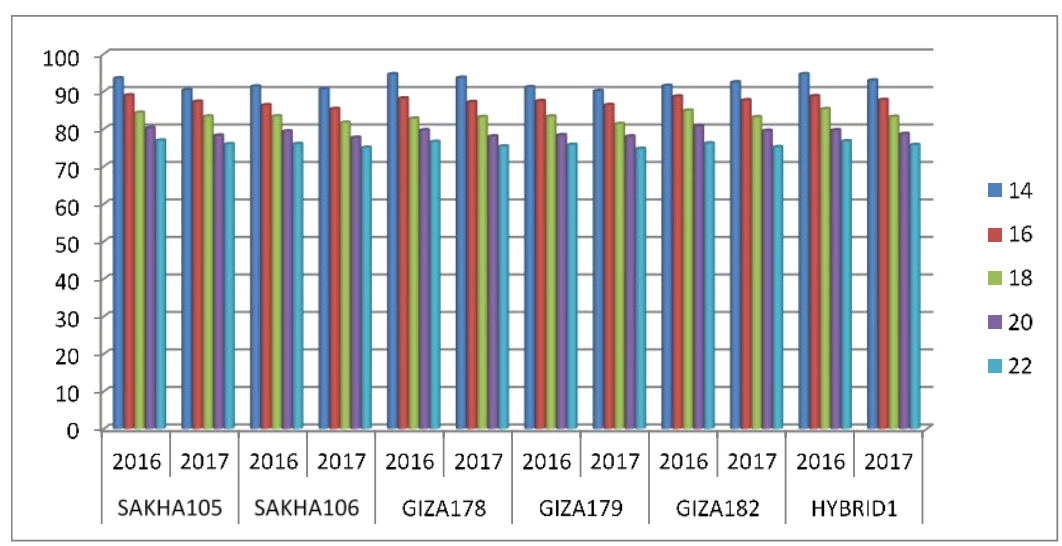

Figure 3. Germination \% as affected by the interaction between some rice varieties and different moisture content during 2016 and 2017 seasons 


$$
-987 \text { - }
$$

The information in Table 8 and Figure 4 showed the interaction between rice varieties and different levels of moisture content for plant height, the lower the moisture content was the longer stature for plant height was recorded in all studied cultivars indicating that low moisture content produce good seedling vigor then normal crop growth rate and high productivity.

Table 8. Plant height (cm) as affected by the interaction between some rice genotypes and different moisture content during 2016 and 2017 seasons

\begin{tabular}{|c|c|c|c|c|c|c|c|c|c|c|c|c|}
\hline \multirow{3}{*}{ Moisture } & \multicolumn{12}{|c|}{ Varieties } \\
\hline & \multicolumn{2}{|c|}{ SAKHA105 } & \multicolumn{2}{|c|}{ SAKHA106 } & \multicolumn{2}{|c|}{ GIZA178 } & \multicolumn{2}{|c|}{ GIZA179 } & \multicolumn{2}{|c|}{ GIZA182 } & \multicolumn{2}{|c|}{ HYBRID1 } \\
\hline & 2016 & 2017 & 2016 & 2017 & 2016 & 2017 & 2016 & 2017 & 2016 & 2017 & 2016 & 2017 \\
\hline 14 & 104.0 & 105.0 & 108.0 & 106.6 & 102.0 & 105.6 & 93.66 & 92.00 & 98.00 & 96.00 & 105.6 & 99.33 \\
\hline 16 & 96.00 & 94.00 & 100.7 & 99.33 & 99.70 & 98.33 & 87.00 & 85.00 & 91.00 & 89.00 & 101.70 & 97.66 \\
\hline 18 & 89.80 & 91.53 & 97.60 & 95.40 & 97.20 & 95.00 & 84.40 & 83.46 & 88.00 & 86.00 & 98.00 & 96.00 \\
\hline 20 & 86.90 & 89.70 & 94.50 & 92.56 & 93.60 & 91.43 & 81.70 & 80.83 & 85.00 & 83.26 & 96.23 & 94.03 \\
\hline 22 & 82.50 & 85.46 & 91.60 & 88.90 & 90.73 & 88.63 & 79.20 & 77.86 & 82.70 & 80.70 & 92.40 & 90.70 \\
\hline $\begin{array}{c}\text { LSD } 0.05 \text { at } \\
2016 / 2017\end{array}$ & & & & & & & 3.264 & & & & & \\
\hline
\end{tabular}

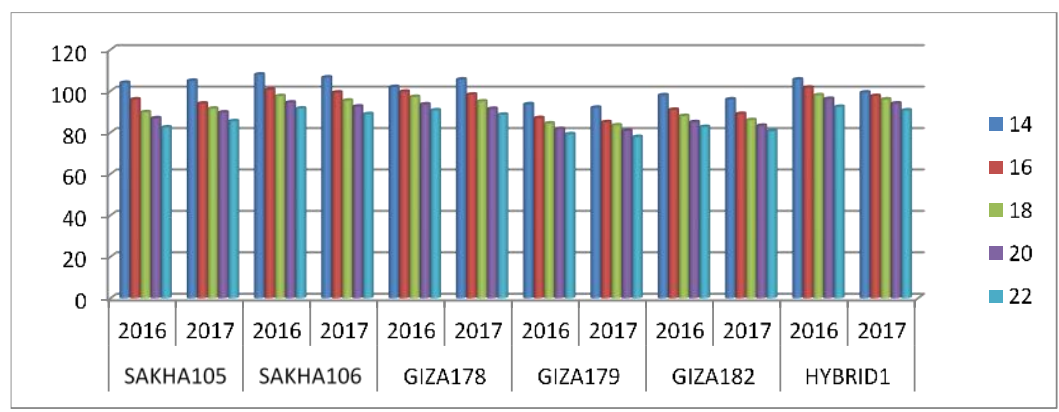

Figure 4. Plant height $(\mathrm{cm})$ as affected by the interaction between some rice and varieties with different moisture content during 2016 and 2017 season

The results in Table 9 and Figure 5 showed the grain yield as affected by interaction between rice varieties and different levels of moisture content during two seasons, the rice variety Egyptian hybrid 1 recorded the highest value with $14 \%$ moisture content compared to SAKHA 105 with $22 \%$ moisture content during the two years.

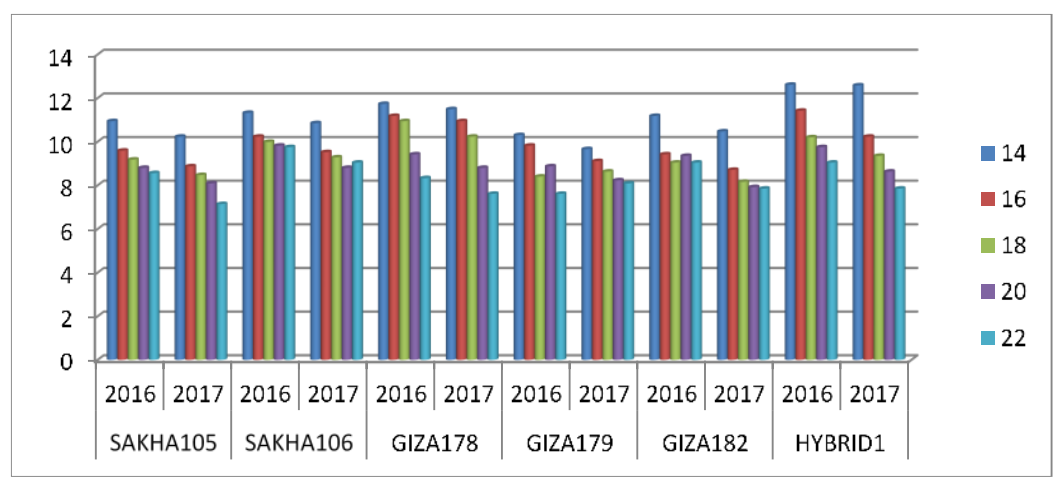

Figure 5. Grain yield (t/ha.) as affected by the interaction between some rice and varieties with different moisture content during 2016 and2017 seasons 
Table 9. Grain yield (t/ha.) as affected by the interaction between some rice and different varieties and moisture content during 2016 and 2017 season

\begin{tabular}{|c|c|c|c|c|c|c|c|c|c|c|c|c|}
\hline \multirow{3}{*}{ Moisture } & \multicolumn{12}{|c|}{ Varieties } \\
\hline & \multicolumn{2}{|c|}{ SAKHA105 } & \multicolumn{2}{|c|}{ SAKHA106 } & \multicolumn{2}{|c|}{ GIZA178 } & \multicolumn{2}{|c|}{ GIZA179 } & \multicolumn{2}{|c|}{ GIZA182 } & \multicolumn{2}{|c|}{ HYBRID1 } \\
\hline & 2016 & 2017 & 2016 & 2017 & 2016 & 2017 & 2016 & 2017 & 2016 & 2017 & 2016 & 2017 \\
\hline 14 & 10.94 & 10.23 & 11.32 & 10.85 & 11.73 & 11.49 & 10.30 & 9.66 & 11.18 & 10.47 & 12.61 & 12.58 \\
\hline 16 & 9.59 & 8.87 & 10.23 & 9.52 & 11.18 & 10.94 & 9.82 & 9.11 & 9.42 & 8.71 & 11.42 & 10.23 \\
\hline 18 & 9.18 & 8.47 & 9.99 & 9.28 & 10.94 & 10.23 & 8.40 & 8.63 & 9.04 & 8.16 & 10.2 & 9.35 \\
\hline 20 & 8.80 & 8.09 & 9.82 & 8.80 & 9.42 & 8.80 & 8.87 & 8.23 & 9.35 & 7.92 & 9.75 & 8.63 \\
\hline 22 & 8.56 & 7.14 & 9.75 & 9.04 & 8.33 & 7.61 & 7.61 & 8.09 & 9.04 & 7.85 & 9.04 & 7.85 \\
\hline $\begin{array}{r}\text { LSD } 0.05 \\
2016 / 20 \\
\end{array}$ & & & & & & & & & & & & \\
\hline
\end{tabular}

The results in Table 10 and Figure 6 showed the interaction between rice varieties and different levels of moisture content for seed set \% in the two years, the Sakha 106 rice varieties with $14 \%$ moisture content recorded the highest for seed set\% compared to Giza 182 rice variety which recorded undesirable value with high moisture content during the two years, indicating that the Giza 182 as indica type was sensitive to high moisture content and low physiological maturity.

\section{Discussion}

High quality seed reflects the need to emphasize seed testing, focusing on physical purity, germination capacity and moisture content, and also seed health tests, varietals purity evaluations and seedling vigor tests. Seed quality control and certification is mainly based on crop inspection and laboratory testing to ensure that, the seed meets minimum standards laid down in the regulations. High quality seed reflects on the increasing national income. Seeds are tested according to the procedures of International Seed Testing Association (ISTA) and Organization for Economic Cooperation and Development (OECD). From the above results it could be concluded that, to increase the seed equality and productivity, the seeds should be harvested at 14\% moisture content, these results were in agreement with Kibar et al. (2010), Genkawa et al. (2008) and Pimratcha et al. (2019). Also, the results indicated that the cultivars with low moisture content should be harvest to get high seed quality, these results were confirmed by Sharif and Ghadi (2013) and Li et al. (2019). Also, the results may be referred to the genetic make-up whereas the Giza 178 having lightweight grain, as well as, indicated to the seed with $14 \%$ moisture content may be enhancement the crop growth rate then enhancement the yield and yield attributes. Dissimilar results obtained by Khalil (2015), the high differences between the rice variety and moisture content for 1000 grain weight. These results may refer to the hybrid which exhibited the hybrid vigor compared to the other varieties the highest and stabile values for grain yield per unit area may be referred to the stable weather condition through growing seasons as shown in Table 1 and Photos 1 and 2 (Abo Yousef et al., 2018; Chu et al., 2018; Fatima et al., 2018; Yong et al., 2019). High quality seeds have the capacity to provide vigorous seedlings over a wide range of environments. Deterioration of high-quality seed can render seed worthless for 


$$
\text { - } 989 \text { - }
$$

planting although its germination percent remains relatively high seed deterioration is a progressive process from the time of physiological maturity until the seed is dead.

Table 10. Seed set \% as affected by the interaction between some rice and different varieties and moisture content during 2016 and 2017 seasons

\begin{tabular}{|c|c|c|c|c|c|c|c|c|c|c|c|c|}
\hline \multirow{3}{*}{ Moisture } & \multicolumn{12}{|c|}{ Varieties } \\
\hline & \multicolumn{2}{|c|}{ SAKHA105 } & \multicolumn{2}{|c|}{ SAKHA106 } & \multicolumn{2}{|c|}{ GIZA178 } & \multicolumn{2}{|c|}{ GIZA179 } & \multicolumn{2}{|c|}{ GIZA182 } & \multicolumn{2}{|c|}{ HYBRID1 } \\
\hline & 2016 & \begin{tabular}{|l|}
2017 \\
\end{tabular} & 2016 & 2017 & 2016 & 2017 & 2016 & 2017 & 2016 & 2017 & 2016 & 2017 \\
\hline 14 & 94.00 & 92.33 & 98.10 & 98.10 & 96.00 & 94.00 & 97.00 & 95.00 & 94.00 & 92.00 & 95.50 & 93.50 \\
\hline 16 & 86.80 & 84.80 & 86.49 & 84.49 & 88.20 & 86.24 & 89.14 & 87.14 & 86.30 & 84.30 & 87.72 & 85.72 \\
\hline 18 & 82.37 & 80.55 & 82.00 & 80.00 & 83.64 & 81.64 & 84.54 & 82.55 & 81.83 & 79.84 & 83.18 & 81.18 \\
\hline 20 & 78.00 & 75.33 & 77.76 & 75.76 & 79.30 & 77.30 & 77.16 & 75.16 & 74.59 & 72.56 & 78.87 & 76.85 \\
\hline 22 & 74.90 & 71.90 & 74.70 & 71.76 & 75.19 & 73.17 & 76.00 & 74.00 & 73.56 & 71.56 & 74.78 & 72.78 \\
\hline $\begin{array}{l}\text { LSD } 0.05 \text { at } \\
2016 / 2017\end{array}$ & & & & & & & 0.533 & & & & & \\
\hline
\end{tabular}

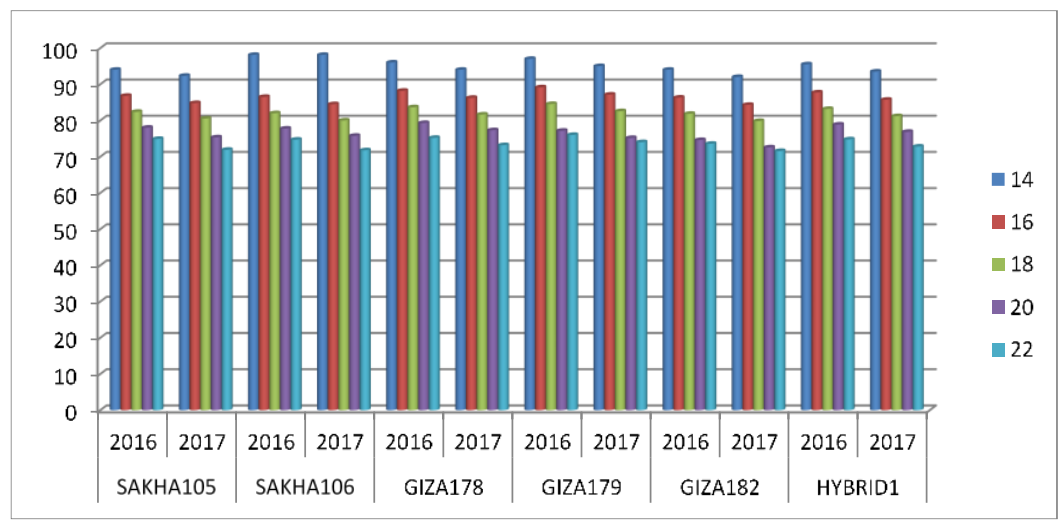

Figure 6. Seed set \% as affected by the interaction between some rice and varieties different moisture content during 2016 and 2017 season

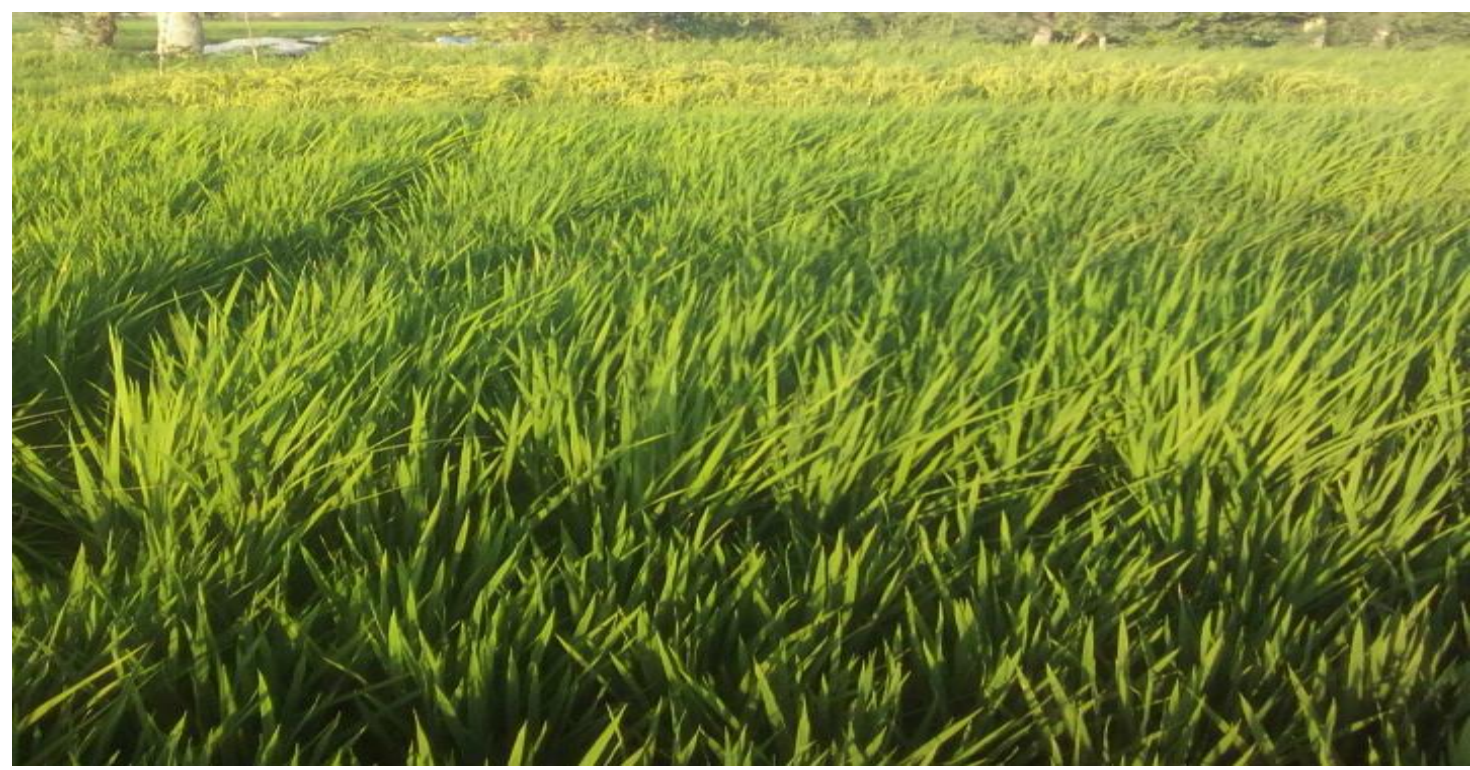

Photo 1. Rice varieties at harvest and the different rice varieties under study 


$$
-990 \text { - }
$$

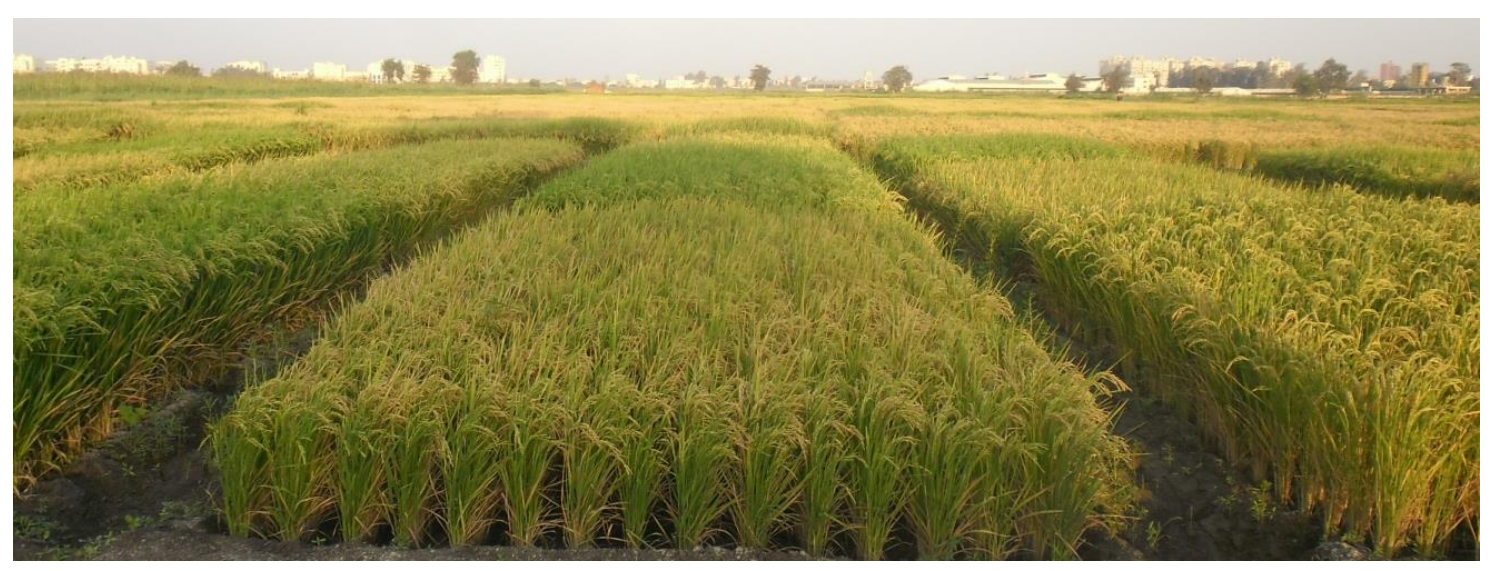

Photo 2. Rice varieties at harvest

\section{Conclusion}

From these results it could be concluded that, the desirable values were recorded for the lowest moisture content, but the highest moisture content undesirable values were recorded for all studied characters, on the other hand the highest seed volume, plant height and 1000 grain weight were recorded in Sakha 106, while the highest germination \% and grain yield (t/ha) were recorded in the Hybrid 2034 and Giza 178, which means seeds dried to $14 \%$ moisture content should be harvested and stored to maintain the seed viability and increase the productivity. Finally, the optimum date for harvesting the rice cultivars under study should be determined.

\section{REFERENCES}

[1] Abo Yousef, M. I., Abd El Aty, M. S., Talha, I. A., Hammoud, S. A. (2018): Response of some rice varieties to different doses of $\mathrm{X}$ rays on the yield and its related characters. - 4th International Conference on Biotechnology Application in Agriculture (ICBAA), 4-7 April, Hurghada, Egypt.

[2] Aidy, I., Draz, R. E., Shatta, A. (2002): Seed production. - Egyptian Journal of Agricultural Research 83(5a): 91-95.

[3] Badawai, I. A. T (2005): Sustainability of rice production in Egypt. - Egyptian Journal of Agricultural Research 83(5a): 23-30.

[4] Chen, C. (2003): Evaluation of air oven moisture content determination methods for rough rice. - Biosystems Engineering 86(4): 447-457.

[5] Chu, G., Chen, T., Chen, S., Xu, C., Wang, D., Zhang, X. (2018): Agronomic performance of drought-resistance rice cultivars grown under alternate wetting and drying irrigation management in southeast China. - The Crop Journal 6(5): 482-494.

[6] Fatima, P., Chand, P., Singh, S. K., Purushottam, Mishra, A., Kumar, P. (2018): Effect of water stress on morphological traits and yield in rice genotypes. - Current Journal of Applied Science and Technology 31(2): 1-8.

[7] Genkawa, A. T. T., Uchino, B. A., Inoue, A. F., Tanaka, B., Hamanaka, D. (2008): Development of a low-moisture content storage system for brown rice: storability at decreased moisture contents. - Biosystems Engineering 4(99): 515-522.

[8] Gomez, K. A., Gomez, A. A. (1984): Statistical Procedures for Agricultural Research. 2nd Ed. - John Wiley and Sons, Inc., New York.

[9] IRRI (2008): Standard Evaluation System for Rice. 3rd Ed. International Rice Testing Programs. - International Rice Research Institute, Manila. 


$$
-991 \text { - }
$$

[10] ISTA (2012): International Seed Testing Association. Seed testing No. 143 April 2012.

[11] Khalil, F., Fouda, M. (2015): Effect of moisture content on seed quality and seedling characters in rice. - Master of Science in (Agronomy) Department of Agronomy, Faculty of Agriculture, Kafr EL-Sheikh University.

[12] Kibar, H., Öztürk, T., Esen, B. (2010): The effect of moisture content on physical and mechanical properties of rice (Oryza sativa L.). - Spanish Journal of Agricultural Research 8(3): 741-749.

[13] Li, R., Li, M., Ashraf, U., Liu, S., Zhang, J. (2019): Exploring the relationships between yield and yield-related traits for rice varieties released in China from 1978 to 2017. Front. Plant Sci. 10: 543.

[14] OECD (2012): Organization for Economic Co-operation and Development. Crop production. OECD-FAO Agricultural Out-look (Edition 2019).

[15] Pimratcha, S., Mungkunkamchaob, T., Kesmalac, T. (2019): Variations in morphological traits, agronomic traits and traits related to drought tolerance in indigenous Thai rice varieties. - Science Asia 45: 99-108.

[16] RRTC (2015): National Rice Research Program: Final Results of 2014 Growing Season. - RRTC, Sakha, Egypt.

[17] Sharif, I., Ghadi, M. (2013): Effect of moisture content on some physical characteristics of three varieties of commercial rice in Iran. - International Journal of Agric. Science 3(1): 62-69.

[18] Yang, X., Wang, B., Chen, L., Li, P., Cao, C. (2019): The different influences of drought stress at the flowering stage on rice physiological traits, grain yield, and quality. Scientific Reports 9: 3742. 